\title{
Association between IL7R polymorphisms and severe liver disease in HIV/HCV coinfected patients: a cross-sectional study
}

\author{
María Guzmán-Fulgencio ${ }^{1}$, Juan Berenguerer,3, María A Jiménez-Sousa', Daniel Pineda-Tenor ${ }^{1}$, \\ Teresa Aldámiz-Echevarria2,3, Pilar García-Broncano', Ana Carrero 2,3 , Mónica García-Álvarez', \\ Francisco Tejerina ${ }^{2,3}$, Cristina Diez ${ }^{2,3}$, Sonia Vazquez-Morón ${ }^{1}$ and Salvador Resino ${ }^{1 *}$
}

\begin{abstract}
Background: Interleukin-7 (IL-7) is a critical factor for T cell development and for maintaining and restoring homeostasis of mature T cells. Polymorphisms at $\alpha$-chain of the IL-7 receptor (IL7R or CD127) gene are related to evolution of HIV-infection, but there are no data concerning the evolution of hepatitis C virus (HCV) infection. The aim of this study was to analyze the association between IL7R polymorphisms and severe liver disease in HCV/HIV coinfected patients.

Methods: We performed a cross-sectional study in 220 naïve patients who underwent a liver biopsy. IL7R polymorphisms (rs6897932, rs987106 and rs3194051) were genotyped using the GoldenGate assay. The outcome variables were: (a) liver biopsy: advanced fibrosis ( $F \geq 3$ ), severe activity grade (A3); (b) non-invasive indexes: advanced fibrosis (APRI $\geq 1.5$ and FIB-4 $\geq 3.25$ ). Logistic regression analysis was used to investigate the association between IL7R polymorphisms and outcome variables. This test gives the differences between groups and the odds ratio (OR) for liver disease.

Results: Patients with rs6897932 CC genotype had higher likelihood of having A3 than patients with rs6897932 $\mathrm{CT} / \mathrm{TT}$ (adjusted odds ratio $(\mathrm{aOR})=4.16 ; \mathrm{p}=0.026)$. Patients with rs987106 TT genotype had higher odds of having $\mathrm{F} \geq 3$ ( $\mathrm{aOR}=3.09 ; \mathrm{p}=0.009$ ) than rs987106 AA/AT carriers. Finally, patients with rs3194051 AA genotype had higher odds of having severe liver fibrosis ( $\mathrm{F} \geq 3$; APRI $\geq 1.5$, and FIB4 $\geq 3.25$ ) than patients with rs3194051 AG/GG genotype $[a O R=2.73(p=0.010) ; a O R=2.52(p=0.029)$; and $a O R=4.01$ ( $p=0.027)$; respectively]. The CTA haplotype (comprised of rs6897932, rs987106, and rs3194051) carriers had higher odds of having $F \geq 3$ (aOR $=1.85 ; p=0.012)$, APRI $\geq 1.5(\mathrm{aOR}=1.94 ; \mathrm{p}=0.023)$, and FIB4 $\geq 3.25(\mathrm{aOR}=2.47 ; \mathrm{p}=0.024)$. Conversely, the CAG haplotype carriers had lower odds of having $F \geq 3(\mathrm{aOR}=0.48 ; \mathrm{p}=0.011), \mathrm{APRI} \geq 1.5(\mathrm{aOR}=0.48 ; \mathrm{p}=0.029)$, and $\mathrm{FIB} 4 \geq 3.25(\mathrm{aOR}=0.29$; $p=0.010)$.
\end{abstract}

Conclusions: The presence of IL7R polymorphisms seems to be related to severe liver disease in HIV/HCV coinfected patients, because patients with unfavorable IL7R genotypes (rs6897932 CC, rs987106 TT, and rs3194051AA) had a worse prognosis of $\mathrm{CHC}$.

Keywords: HIV/AIDS, Hepatic fibrosis, Chronic hepatitis C, IL7R, SNPS

\footnotetext{
*Correspondence: sresino@isciii.es

${ }^{1}$ Unidad de Infección Viral e Inmunidad, Centro Nacional de

Microbiología, Instituto de Salud Carlos III (Campus Majadahonda),

Carretera Majadahonda-Pozuelo, Km 2.2, Majadahonda, 28220 Madrid,

Spain

Full list of author information is available at the end of the article
} 


\section{Background}

Interleukin-7 (IL-7) is required for $\mathrm{T}$ cell development and for maintaining and restoring homeostasis of mature $\mathrm{T}$ cells. IL-7 is a critical factor in maintaining or inducing an effective antiviral CD4+ and CD8+ T cell responses [1]. IL-7 is implicated in the proliferation and survival of early $\mathrm{T}$ and $\mathrm{B}$ cells in the thymus and bone marrow, respectively. Besides, in the periphery, IL-7 enhances survival and proliferation of naïve and memory $\mathrm{T}$ cells, regulating the $\mathrm{T}$ cell homeostasis [2]. The responsiveness of IL-7 is dependent on expression of the IL-7 receptor, which is composed of the high-affinity $\alpha$-chain (IL7R $\alpha$ or CD127) and the common cytokine receptor gamma chain (CD132) [3].

In human immunodeficiency virus (HIV) infection, the interaction between IL-7 and CD127 has impact on development, survival, and proliferation of CD4+ T cells [4]. During HIV infection, IL-7 regulatory pathway is activated and IL-7 levels are increased, but it is not enough to maintain $\mathrm{T}$ cell homeostasis due to progressive destruction of $\mathrm{CD} 4+\mathrm{T}$ cell [5]. In hepatitis $\mathrm{C}$ virus $(\mathrm{HCV})$ infection, hepatocytes stimulated by type I interferon (IFN) are able to produce IL-7 and eventually lead to viral clearance and disease resolution in the liver [6]; and the early expression of CD127 on HCV-specific $\mathrm{T}$ cells predicts the $\mathrm{HCV}$ clearance during acute $\mathrm{HCV}$ infection [7]. However, IL-7 and CD127 levels are significantly diminished during chronic $\mathrm{HCV}$ infection, leading to an impaired $\mathrm{HCV}$-specific cytotoxic $\mathrm{T}$ cell reactivity $[8,9]$.

The IL7R $\alpha$ (CD127) is encoded by IL7R gene, which plays an essential role in several human diseases. Thus, IL7R polymorphisms have been studied in several infectious diseases [10,11] and autoimmune diseases [12], showing a key role in the evolution of patients. In HIV infection, $I L 7 R$ polymorphisms have been associated with the decline in the CD4+ cell count in untreated HIV-infected subjects [13], and CD4+ T-cell recovery in HIV-infected patients on combination antiretroviral therapy (cART) [14]. In HCV infection, we have recently reported an association between $I L 7 R$ polymorphisms and virological response to HCV therapy with pegylated interferon alpha plus ribavirin (pegIFN $\alpha /$ ribavirin) [15]. Thus, $I L 7 R$ polymorphisms seem to play a crucial role in the physiopathology of these diseases.

The cART has made of HIV infection a chronic manageable disease in high income countries [16]. In this setting, chronic hepatitis $\mathrm{C}(\mathrm{CHC})$ has turned into an important comorbidity and a major cause of death in HIV/HCV coinfected patients [17-19], since HIV infection accelerates the natural history of $\mathrm{CHC}$ and increases liver-related morbidity and mortality [20-22]. Interestingly, uncontrolled HIV replication and low CD4 counts are both associated with accelerated liver fibrosis progression in HIV/HCV coinfected patients [23], suggesting that earlier use of antiretroviral therapy could ameliorate this harmful effect [24].

The aim of this study was to analyze the association between IL7R polymorphisms (rs6897932, rs987106, and rs3194051) and severe liver disease in HCV/HIV coinfected patients.

\section{Patients and methods}

\section{Study design and patients}

We carried out a cross-sectional study in HIV/HCV coinfected patients that underwent a liver biopsy at Hospital Gregorio Marañón (Madrid, Spain) between September 2000 and November 2008. All patients were of European ancestry.

Liver biopsies were performed on patients who were potential candidates for anti-HCV therapy and had not received previous interferon therapy (naïve for $\mathrm{HCV}$ treatment). Selection criteria were: no clinical evidence of hepatic decompensation, detectable HCV RNA by polymerase chain reaction (PCR), negative hepatitis $\mathrm{B}$ surface antigen, availability of DNA sample, CD4+ lymphocyte count higher than 200 cells $/ \mu \mathrm{L}$, and stable cART for at least 6 months before study entry or no need for cART according to treatment guidelines used in the study period $[25,26]$. Patients with active opportunistic infections, active drug addiction, and other concomitant severe diseases were excluded. Thus, from our cohort of $361 \mathrm{HIV} / \mathrm{HCV}$ coinfected patients with liver biopsy data, only 220 patients had data available of $I L 7 R$ genotypes.

The study was conducted in accordance with the Declaration of Helsinki and patients gave their written consent for the study. The Institutional Review Board and the Research Ethic Committee of the Instituto de Salud Carlos III approved the study.

\section{Epidemiological and clinical data}

Clinical and epidemiological data were obtained from medical records. Consumption of more than $50 \mathrm{~g}$ of alcohol per day for at least 12 months was considered as a high intake. Body mass index (BMI) was calculated as the weight in kilograms divided by the square of the height in meters. The duration of $\mathrm{HCV}$ infection for patients with a history of intravenous drug use (IDU; $87.7 \%$ of patients) was estimated starting from the first year they shared needles and other injection paraphernalia, which are the most relevant risk practices for HCV transmission [27]. The duration of HCV infection was not calculated when the date of initiation of their HCV infection could not be determined with certainty $(\mathrm{n}=19)$.

Biochemistry panel was measured using an autoanalyzer Hitachi 912 (Boehringer Mannheim, Germany), 
while patients were fasting. The degree of insulin resistance was estimated for each patient using the homeostatic model assessment (HOMA) [28]: fasting plasma glucose $(\mathrm{mmol} / \mathrm{L})$ times fasting serum insulin $(\mathrm{mU} / \mathrm{L})$ divided by 22.5 [28]. Non-invasive liver fibrosis indexes were calculated according to the formula originally described for the aspartate aminotransferase to platelet ratio index (APRI): aspartate aminotransferase (AST) $[\mathrm{U} / \mathrm{L}] /$ upper limit of normal for AST (ULN)/ (platelet $\left.\left[10^{9} / \mathrm{L}\right]\right) \times 100[29]$ and the FIB-4 index: age [years] $\times$ AST $[\mathrm{U} / \mathrm{L}] /\left(\right.$ platelets $\left.\left[10^{9} / \mathrm{L}\right]\right) \times($ alanine aminotransferase $(\mathrm{ALT})[\mathrm{U} / \mathrm{L}])^{1 / 2}$ ) [30]. Although these indexes may have a poor ability to identify patients with intermediate stage of fibrosis [31], we have previously reported that the diagnostic performance of APRI and FIB-4 indexes were acceptable for diagnosis of advanced fibrosis in HIV/HCV-coinfected patients [32].

\section{$\mathrm{HCV}$ assays}

$\mathrm{HCV}$ infection was documented in all patients by enzyme-linked immunosorbent assay and PCR test. HCV genotype was determined by hybridization of biotinlabeled PCR products to oligonucleotide probes bound to nitrocellulose membrane strips (INNO-LiPA HCV II, Innogenetics, Ghent, Belgium). Plasma HCV-RNA viral load was measured by PCR (Cobas Amplicor HCV Monitor Test, Branchburg, NJ, USA) and real-time PCR (COBAS AmpliPrep/COBAS TaqMan HCV test); and results were reported in terms of international units per milliliter $(\mathrm{IU} / \mathrm{mL})$, with a lower limit of detection of $10 \mathrm{IU} / \mathrm{mL}$.

\section{Liver biopsy}

Liver biopsies were performed as we described previously [32]. The samples were always evaluated by the same pathologist, who was unaware of the patients' clinical or laboratory data. Liver fibrosis and necroinflammatory activity were estimated according to Metavir score as follows [33]: F0, no fibrosis; F1, mild fibrosis; F2, significant fibrosis; F3, advanced fibrosis; and F4, definite cirrhosis. The degree of necroinflammation (activity grade) was scored as follows: A0, no activity; A1, mild activity; A2, moderate activity; A3, severe activity.

\section{Genotyping of IL7R polymorphisms}

We have analyzed the most common single nucleotide polymorphisms (SNPs) including at IL7R gene, using the databases of HapMap Project (http://snp.cshl.org/ cgi-perl/gbrowse/hapmap_B35/) and NCBI (dbSNP) (http://www.ncbi.nlm.nih.gov/entrez/). The selection criteria were: (1) SNPs located at a putative regulatory region, although their effect has not been tested or demonstrated. (2) Allelic frequency greater than $20 \%$ in
European people, because it is easier to detect a modest individual effect with a high SNP frequency $>20 \%$ in the population when small sample sizes are used [34]. (3) A tag-SNP was selected when more than 1 SNP per gene was found and they had high linkage disequilibrium (LD). In summary, three SNPs [rs987106 (intronic region), rs6897932 (exon 6) and rs3194051 (exon 8)] were used for the genetic association study.

Genomic DNA was extracted from peripheral blood with Qiagen kit (QIAamp DNA Blood Midi/Maxi; Qiagen, Hilden, Germany). DNA samples were genotyped at the Spanish National Genotyping Center (CeGen; http:// www.cegen.org/) using GoldenGate assay with VeraCode ${ }^{\circ}$ Technology (Illumina Inc. San Diego, CA, USA) [35].

\section{Outcome variables}

We analyzed several outcome variables related to severity of liver disease [31]: (a) liver biopsy: advanced fibrosis $(\mathrm{F} \geq 3$ ), severe activity grade (A3); (b) non-invasive indexes: advanced fibrosis (APRI $\geq 1.5$ and FIB-4 $\geq 3.25$ ). These CHC-related outcomes were developed after a minimum follow-up time of 10 years with $\mathrm{HCV}$ infection.

\section{Statistical analysis}

For the description of the study population, $\mathrm{p}$ values were estimated with Chi square test for categorical variables.

The genetic analysis was carried out according to additive, recessive and dominant models, selecting the model that best fitted the outcome variable analyzed in each case. The genetic association study was performed via logistic regression analysis. This test gives the differences between groups and the odds ratio (OR) for liver disease. Each regression analysis was always adjusted by the most significant co-variables associated with each one of the outcome variables, avoiding the over-fitting of the regression. The co-variables were selected by "Stepwise" algorithm (at each step, factors were considered for removal or entry: a p value for entry and exit of 0.15 and 0.20 , respectively), including gender, age, alcohol intake, BMI, HOMA, nadir CD4+ T-cells, AIDS, undetectable HIV-RNA ( $<50$ copies/ml), CD4+ T-cells, time of $\mathrm{HCV}$ infection, time on CART, type of cART, HCV-RNA $\geq 500,000 \mathrm{IU} / \mathrm{ml}$, and $\mathrm{HCV}$ genotype. The percentage of patients that were excluded in each of the multivariable analyses due to incomplete data of covariates was always $<5 \%$.

These analyses were performed by using the IBM SPSS Statistics for Windows, Version 21.0 (IBM Corp, Chicago, Armonk, NY, USA). In addition, pair-wise LD and Hardy-Weinberg equilibrium (HWE) analyses were computed by Haploview 4.2 software. Haplotype-based association testing was performed using Plink software 
(http://pngu.mgh.harvard.edu/ purcell/plink/) and each haplotype was compared with the rest of haplotypes (there was no reference category). All p values were twotailed and statistical significance was defined as $\mathrm{p}<0.05$.

\section{Results}

\section{Characteristics of the patients}

Table 1 shows the epidemiological and clinical characteristics of $220 \mathrm{HIV} / \mathrm{HCV}$ coinfected patients.

\section{Characteristics of IL7R polymorphisms}

A strong LD (non-random association of alleles at different loci) among IL7R polymorphisms was found $\left(D^{\prime} \geq 0.999\right)$, meaning that there is no evidence for recombination between these SNPs. However, the r-square among SNPs was low ( $r$-square $<0.50$ ), meaning that the $I L 7 R$ polymorphisms did not provide exactly the same information and the $I L 7 R$ polymorphisms cannot substitute one for another (Figure 1a). Additionally, all SNPs had a minimum allele frequency (MAF) $>5 \%$, displayed missing values $<5 \%$, and were in HWE ( $p>0.05$ ) (Figure $1 b)$.

\section{IL7R polymorphisms and severe liver disease}

For rs6897932 polymorphism (Table 2A), patients with rs6897932 CC genotype had higher frequency of A3 in liver biopsy $(p=0.023)$ and had higher likelihood of having A3 than patients with rs6897932 CT/TT [adjusted odds ratio $(\mathrm{aOR})=4.16 ; \mathrm{p}=0.026]$.

For rs987106 polymorphism (Table 2B), patients with rs987106 TT genotype had higher frequency of severe fibrosis $(F \geq 3$, APRI $\geq 1.5$, and FIB4 $\geq 3.25)$ than patients with rs987106 AA/AT genotype $(\mathrm{p}=0.019, \mathrm{p}=0.033$, and $\mathrm{p}=0.050$; respectively). Furthermore, rs987106 TT genotype was related to higher odds of having $\mathrm{F} \geq 3$ $(\mathrm{aOR}=3.09 ; \mathrm{p}=0.009$ ).

For rs3194051 polymorphism (Table 2C), patients with rs3194051 AA genotype had higher frequency of $\mathrm{F} \geq 3(\mathrm{p}=0.026)$, APRI $\geq 1.5(\mathrm{p}=0.016)$, and FIB4 $\geq 3.25$ ( $p=0.022)$. Besides, patients with rs3194051 AA genotype had higher odds of having severe liver fibrosis ( $\mathrm{F} \geq 3$; APRI $\geq 1.5$, and FIB4 $\geq 3.25$ ) than patients with rs3194051 AG/GG genotype [aOR $=2.73(\mathrm{p}=0.010)$; $\mathrm{aOR}=2.52(\mathrm{p}=0.029) ;$ and $\mathrm{aOR}=4.01(\mathrm{p}=0.027)$; respectively].

Three major haplotypes (comprised of rs6897932, rs987106, and rs3194051) were found (Table 3): CTA, CAG, and TAA. The CTA haplotype carriers had higher odds of having $\mathrm{F} \geq 3(\mathrm{aOR}=2.01 ; \mathrm{p}=0.007)$, $\mathrm{APRI} \geq 1.5$ $(\mathrm{aOR}=1.98 ; \mathrm{p}=0.028)$, and FIB4 $\geq 3.25(\mathrm{aOR}=2.69$; $\mathrm{p}=0.023)$. Conversely, CAG haplotype carriers had
Table 1 Clinical and epidemiological characteristics of HIV/HCV-coinfected patients

\begin{tabular}{|c|c|}
\hline Characteristics & All patients \\
\hline No. (\%) & $220(100 \%)$ \\
\hline Male, n (\%) & $162(73.6 \%)$ \\
\hline Age, years & $39.8(37.4 ; 44)$ \\
\hline HIV acquired by IDU, n (\%) & $193(87.7 \%)$ \\
\hline Years since HCV infection & $21.3(17.1 ; 24.4)$ \\
\hline Prior AIDS, n (\%) & $60(27.3 \%)$ \\
\hline cART, n (\%) & $183(83.2 \%)$ \\
\hline Time on CART, years & $4.4(2.5 ; 6.7)$ \\
\hline \multicolumn{2}{|l|}{ Current cART protocols, n (\%) } \\
\hline PI-based & $50(22.7 \%)$ \\
\hline NNRTI-based & $114(51.8 \%)$ \\
\hline NRTI-based & $129(58.6 \%)$ \\
\hline \multicolumn{2}{|l|}{ Metabolic markers } \\
\hline $\mathrm{BMI}, \mathrm{kg} / \mathrm{m}^{2}$ & $22.4(20.8 ; 24.6)$ \\
\hline $\mathrm{BMI} \geq 25 \mathrm{~kg} / \mathrm{m}^{2}$ & $50(22.9 \%)$ \\
\hline HOMA & $2.10(1.27 ; 3.73)$ \\
\hline $\mathrm{HOMA} \geq 3$ & $71(33.5 \%)$ \\
\hline \multicolumn{2}{|l|}{ HIV markers } \\
\hline Nadir CD4+, T cells/ $\mu \mathrm{L}$ & $192(84 ; 318)$ \\
\hline $\mathrm{CD} 4+, \mathrm{T}$ cells/ $\mu \mathrm{L}$ & $467(324 ; 672)$ \\
\hline HIV-RNA < 50 copies/mL, n (\%) & $162(73.6 \%)$ \\
\hline \multicolumn{2}{|l|}{ HCV markers, n (\%) } \\
\hline HCV-RNA $\geq 500.000 \mathrm{IU} / \mathrm{ml}$ & $162(74.7 \%)$ \\
\hline HCV genotype & $216(98.2 \%)$ \\
\hline HCV-GT1 & $123(55.9 \%)$ \\
\hline HCV-GT2 & $5(2.3 \%)$ \\
\hline HCV-GT3 & $50(22.7 \%)$ \\
\hline HCV-GT4 & $38(17.3 \%)$ \\
\hline \multicolumn{2}{|l|}{ Metavir score, n (\%) } \\
\hline Significant fibrosis ( $F \geq 2$ ) & $109(49.5 \%)$ \\
\hline Advanced fibrosis ( $F \geq 3$ ) & $49(23.3 \%)$ \\
\hline Cirrhosis (F4) & $23(10.5 \%)$ \\
\hline Moderate activity grade $(A \geq 2)$ & $114(52.8 \%)$ \\
\hline Severe activity grade (A3) & $24(11.1 \%)$ \\
\hline \multicolumn{2}{|l|}{ Fibrosis indexes } \\
\hline APRI & $0.75(0.45 ; 1.30)$ \\
\hline $\mathrm{APRI} \geq 1.5$ & $36(17.2 \%)$ \\
\hline FIB-4 & $1.43(1.03 ; 2.03)$ \\
\hline FIB- $4 \geq 3.25$ & $20(9.6 \%)$ \\
\hline
\end{tabular}

Values expressed as absolute numbers (\%) and median (percentile 25; percentile 75).

AIDS acquired immunodeficiency syndrome, $A P R I$ aspartate aminotransferase to platelet ratio, $B M I$ body mass index, $C A R T$ combination antiretroviral therapy, HCV hepatitis $C$ virus, HCV-RNA HCV plasma viral load, HIV human immunodeficiency, HIV-RNA HIV plasma viral load, HOMA homeostasis model assessment, IDU intravenous drug users, NNRTI no nucleoside analog reverse-transcriptase inhibitors, NRTI nucleoside analog reverse-transcriptase inhibitors, PI protease inhibitors. 
a

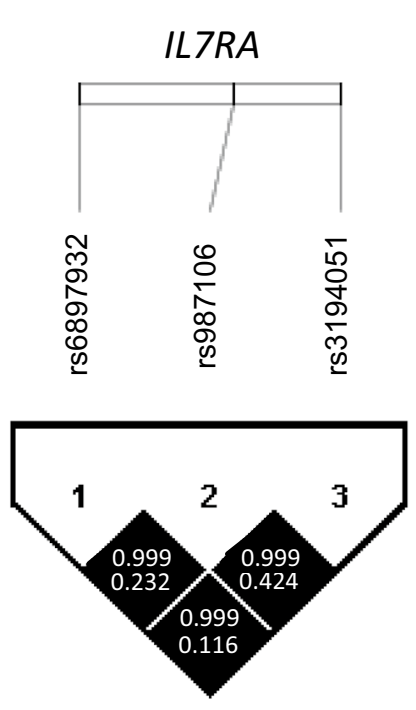

b

\begin{tabular}{cccccc} 
Gene & SNP & Position & HWE p-value & Alleles & MAF \\
\hline IL7RA & rs987106 & 35875593 & 0.159 & A/T & 0.201 \\
& rs6897932 & 35874575 & 0.846 & C/T & 0.479 \\
& rs3194051 & 35876274 & 0.326 & A/G & 0.315
\end{tabular}

Figure 1 a Pairwise linkage disequilibrium (LD) patterns for three polymorphisms through IL7RA regions. Each diagonal represents a different SNP, with each square representing a pairwise comparison between two SNPs. b Allele and genotype frequencies, Hardy-Weinberg Equilibrium (HWE) and linkage disequilibrium (LD) for IL7RA polymorphisms (rs987106, rs6897932 and rs3194051) in HIV/HCV coinfected patients. HWE Hardy-Weinberg equilibrium, MAF minor allele frequency, SNP single nucleotide polymorphism.

lower odds of having $\mathrm{F} \geq 3(\mathrm{aOR}=0.42 ; \mathrm{p}=0.004)$, APRI $\geq 1.5(\mathrm{aOR}=0.45 ; \mathrm{p}=0.026)$, and FIB4 $\geq 3.25$ $(\mathrm{aOR}=0.24 ; \mathrm{p}=0.007)$.

\section{Discussion}

To our knowledge, this study is the first description of the relation between IL7R polymorphisms and severity of liver disease in HIV/HCV-coinfected patients. The major findings of our study were: (1) IL7R rs6897932 CC was associated with higher odds of having severe activity necroinflammatory grade; (2) IL7R rs987106 TT and rs3194051 AA genotypes were related to increased odds of having severe fibrosis; and (3) IL7R CTA haplotype was associated with severe fibrosis while IL7R CAG haplotype had a protective nature. Moreover, these relationships were less evident when patients were stratified by HCV genotype (data not shown), perhaps due to a smaller sample size of the groups.

The rs6897932 $\mathrm{C} / \mathrm{T}$ polymorphism is a missense variant located in the alternatively spliced exon 6 of IL7R gene, causing a substitution of threonine with isoleucine in the transmembrane domain of the $I L 7 R$ gene. This polymorphism is implicated in splicing regulation, where the $C$ allele leads to increased skipping of exon 6 by putatively disrupting an exonic splicing motif [36], increasing the production of sCD127 (soluble isoform) and decreasing CD127 levels (membrane-bound isoform). In this setting, rs6897932 CC genotype has been associated to higher plasma levels of sCD127 in Caucasian HIVinfected patients [14, 37], which binds to circulating IL-7 and decreases the IL-7 bioavailability, limiting its effects [38]. Thus, rs6897932 C allele has been related to slower CD4+ T-cell recovery in European HIV infected patients on cART [39]. In our study, patients with rs6897932 CC genotype had higher odds of severe necroinflammatory activity grade. Given that the IL7R rs6897932 CC genotype is related to increased risk of autoimmune diseases $[36,40]$, it is possible to speculate that higher level of sCD127 may confer worse immunological control of $\mathrm{HCV}$ infection in liver, with a higher necroinflammatory activity in liver biopsy. However, further studies investigating the underlying mechanisms are warranted.

In our study we also found that rs987106 TT and rs3194051 AA genotypes were related to higher odds of having severe liver fibrosis. The rs987106 polymorphism is an intronic variant between exons 6 and 7 of IL7R gene and rs3194051 is a missense polymorphism located at exon 8 . These polymorphisms are predicted 
Table 2 Relationship between IL7RA polymorphisms and severe liver disease in HIV/HCV-coinfected patients

\begin{tabular}{|c|c|c|c|c|c|}
\hline & \multicolumn{3}{|l|}{ Unadjusted } & \multicolumn{2}{|l|}{ Adjusted } \\
\hline & $\mathrm{CT} / \mathrm{TT}$ & $\mathrm{CC}$ & $P^{a}$ & aOR $(95 \% \mathrm{Cl})$ & $p^{b}$ \\
\hline \multicolumn{6}{|l|}{ (A) rs6897932 } \\
\hline$F \geq 3$ & $20.5 \%(17 / 83)$ & $23.4 \%(32 / 137)$ & 0.619 & $1.14(0.54 ; 2.32)$ & 0.735 \\
\hline $\mathrm{APRI} \geq 1.5$ & $15 \%(12 / 80)$ & $18.6 \%(24 / 129)$ & 0.502 & $1.14(0.48 ; 2.68)$ & 0.770 \\
\hline $\mathrm{FIB} 4 \geq 3.25$ & $10 \%(8 / 80)$ & $9.3 \%(12 / 129)$ & 0.868 & $0.80(0.25 ; 2.56)$ & 0.705 \\
\hline \multirow[t]{3}{*}{$\mathrm{A} 3$} & $4.9 \%(4 / 82)$ & $14.9 \%(20 / 134)$ & 0.023 & $4.16(1.19 ; 14.59)$ & 0.026 \\
\hline & \multicolumn{3}{|l|}{ Unadjusted } & \multicolumn{2}{|l|}{ Adjusted } \\
\hline & AA/AT & TT & $P^{a}$ & aOR $(95 \% \mathrm{Cl})$ & $\mathbf{p}^{b}$ \\
\hline \multicolumn{6}{|l|}{ (B) rs987106 } \\
\hline$F \geq 3$ & $18.8 \%(32 / 170)$ & $34.7 \%(17 / 49)$ & 0.019 & $3.09(1.32 ; 7.22)$ & 0.009 \\
\hline $\mathrm{APRI} \geq 1.5$ & $14.3 \%(23 / 161)$ & $27.7 \%(13 / 47)$ & 0.033 & $1.84(0.72 ; 4.70)$ & 0.201 \\
\hline $\mathrm{FIB} 4 \geq 3.25$ & $7.5 \%(12 / 161)$ & $17 \%(8 / 47)$ & 0.050 & $2.33(0.67 ; 8.05)$ & 0.181 \\
\hline \multirow[t]{3}{*}{$\mathrm{A} 3$} & $10.1 \%(17 / 168)$ & $14.9 \%(7 / 47)$ & 0.358 & $1.82(0.63 ; 5.23)$ & 0.269 \\
\hline & \multicolumn{3}{|l|}{ Unadjusted } & \multicolumn{2}{|l|}{ Adjusted } \\
\hline & $\mathrm{AG} / \mathrm{GG}$ & AA & $P^{a}$ & aOR $(95 \% \mathrm{Cl})$ & $\mathbf{p}^{b}$ \\
\hline \multicolumn{6}{|l|}{ (C) rs3194051 } \\
\hline$F \geq 3$ & $16.7 \%(20 / 120)$ & $29.3 \%(29 / 99)$ & 0.026 & $2.73(1.22 ; 5.87)$ & 0.010 \\
\hline $\mathrm{APRI} \geq 1.5$ & $11.5 \%(13 / 113)$ & $24.2 \%(23 / 95)$ & 0.016 & $2.52(1.10 ; 5.77)$ & 0.029 \\
\hline $\mathrm{FIB} 4 \geq 3.25$ & $5.3 \%(6 / 113)$ & $14.7 \%(14 / 95)$ & 0.022 & $4.01(1.17 ; 13.71)$ & 0.027 \\
\hline A3 & $12.6 \%(15 / 119)$ & $9.4 \%(9 / 96)$ & 0.455 & $0.79(0.30 ; 2.10)$ & 0.634 \\
\hline
\end{tabular}

Statistically significant differences are shown in italics.

HCV hepatitis $C$ virus, HIV human immunodeficiency virus, $C H C$ chronic hepatitis $C, 95 \% \mathrm{Cl} 95 \%$ of confidence interval, aOR adjusted odds ratio, $p$ value level of significance, $A 3$ severe activity grade (Metavir), $F \geq 3$ advanced liver fibrosis (Metavir), APRI aspartate aminotransferase to platelet ratio index.

${ }^{a} \mathrm{p}$ values were calculated by Chi squared test.

b $p$ values were calculated by multivariate logistic regression adjusted by the most important clinical and epidemiological characteristics (see "Statistical analysis" section).

Table 3 Association of IL7RA haplotypes (rs987106, rs6897932 and rs13126816) with severe liver disease in HIV/HCV coinfected patients

\begin{tabular}{|c|c|c|c|c|c|c|}
\hline \multicolumn{5}{|c|}{ IL7RA haplotypes } & \multicolumn{2}{|l|}{ Adjusted } \\
\hline rs6897932 & rs987106 & rs3194051 & Freq. & Outcomes & aOR $(95 \% \mathrm{Cl})$ & $p$ value \\
\hline \multirow[t]{4}{*}{ C } & $\mathrm{T}$ & A & $47.9 \%$ & $F \geq 3$ & $2.01(1.19 ; 3.40)$ & 0.007 \\
\hline & & & & $\mathrm{APRI} \geq 1.5$ & $1.98(1.06 ; 3.71)$ & 0.028 \\
\hline & & & & $\mathrm{FIB} 4 \geq 3.25$ & $2.69(1.10 ; 6.60)$ & 0.023 \\
\hline & & & & A3 & NA & - \\
\hline \multirow[t]{4}{*}{ C } & A & G & $31.5 \%$ & $F \geq 3$ & $0.42(0.22 ; 0.78)$ & 0.004 \\
\hline & & & & $\mathrm{APRI} \geq 1.5$ & $0.45(0.22 ; 0.94)$ & 0.026 \\
\hline & & & & $\mathrm{FIB} 4 \geq 3.25$ & $0.24(0.07 ; 0.76)$ & 0.007 \\
\hline & & & & A3 & NA & - \\
\hline \multirow[t]{4}{*}{$\mathrm{T}$} & A & A & $20.1 \%$ & $F \geq 3$ & $0.86(0.44 ; 1.67)$ & 0.647 \\
\hline & & & & $\mathrm{APRI} \geq 1.5$ & $0.92(0.42 ; 2.04)$ & 0.838 \\
\hline & & & & $\mathrm{FIB} 4 \geq 3.25$ & $1.07(0.35 ; 3.26)$ & 0.904 \\
\hline & & & & A3 & NA & - \\
\hline
\end{tabular}

P values were calculated by multivariate logistic regression adjusted by the most important clinical and epidemiological characteristics (see "Statistical analysis" section). Statistically significant differences are shown in italics.

95\% Cl 95\% of confidence interval, aOR adjusted odds ratio, $p$ value level of significance, $A 3$ severe activity grade (Metavir), $F \geq 3$ advanced liver fibrosis (Metavir), $A P R I$ aspartate aminotransferase to platelet ratio index, NA not available due to a low number of patients in one of the groups. 
to be involved in post-transcriptional regulation and besides, rs3194051 is also predicted to be implicated in proximal transcriptional regulation of $\mathrm{CD} 127$, according to an in silico analysis by using rSNPBase software [41]. In regards to rs987106, previous articles have described an association between rs987106 TT genotype and higher sCD127 levels [14] and rapid AIDS progression [13]. The rs3194051 polymorphism, a tag SNP of $I L 7 R$ haplotype 4 in European populations, has been associated with highest CD127 on CD4+ T-cell, higher frequencies of recent thymic emigrants, and lower plasma sCD127 levels in patients with multiple sclerosis [42]. Thus, the rs3194051 A allele ancestral would be associated with lower CD127 on CD4+ T-cell, lower frequencies of recent thymic emigrants, and higher plasma sCD127 levels. Furthermore, rs3194051 A allele has been associated with slower CD4+ recovery in HIV infected patients on cART [14] and lower odds of achieving sustained virological response (SVR) after pegIFN $\alpha /$ ribavirin in $\mathrm{HIV} / \mathrm{HCV}$ coinfected patients [15].

Moreover, as noted in the preceding paragraphs, unfavorable alleles of these three IL7R polymorphisms (rs6897932 C, rs987106 T, and rs3194051 A) have been related to low CD4+ T-cells and rapid AIDS progression in Caucasian naïve HIV infected patients [13] and slower CD4+ recovery in patients on cART [14, 39]. Besides, uncontrolled HIV replication and low CD4 counts are both associated with accelerated liver fibrosis progression in HIV/HCV coinfected patients [23]. Thus, unfavorable IL7R genotypes (rs6897932 CC, rs987106 TT, and rs3194051 AA) could lead to an increased risk of severe liver disease, by decreasing CD4+ cells count and enhancing AIDS progression in $\mathrm{HIV} / \mathrm{HCV}$ coinfected patients [43].

In our study, IL7R haplotypes (comprised of rs6897932, rs987106, and rs3194051) were also investigated to verify whether they could improve the association of severe fibrosis compared to IL7R polymorphisms alone. We found that CTA haplotype was associated with higher odds of having severe liver fibrosis; while CAG haplotype (comprised of one allele associated with higher sCD127 levels and two alleles related to lower sCD127 levels) was associated with lower odds of having severe liver fibrosis. However, OR values were similar to those obtained for individual SNPs. In this regard, we also recently reported that IL7R CTA haplotype (three alleles associated with higher sCD127 levels) was related to lower odds of achieving a SVR [15].

According to what we have discussed until now, IL7R polymorphisms are related to increased odds of having severity of liver disease, possibly due to regulation of sCD127 levels. Previous reports have suggested that
$I L-7 R$ polymorphisms may have an influence on T-cell development and homeostasis, and thereby might contribute to an altered immune regulation [42, 44]. Moreover, the $\mathrm{CHC}$ progression, which includes cirrhosis, end-stage liver disease, and hepatocellular carcinoma, is more rapid in HIV-infected patients, possibly because a damaged immune system may increase the risk for $\mathrm{CHC}$ progression among persons infected with HIV [45-47]. Therefore, one should not rule out the possible influence of $I L 7 R$ polymorphisms in the development of end-stage of liver disease and hepatocellular carcinoma in $\mathrm{HIV} / \mathrm{HCV}$ coinfected patients.

In our study, we compared the $I L 7 R$ genotype frequencies depending on the presence of each of the outcome variables (independent events), which generated a high number of comparisons. There is a considerable controversy about adjusting the "p value" after multiple tests on clinical-orientated studies [48, 49]. In our study there was a hypothesis supported by theory and previous reports in several infectious diseases [10,11], including HIV infected subjects $[13,14]$ and $\mathrm{HIV} / \mathrm{HCV}$ coinfected patients [15], and showing a key role of $I L 7 R$ polymorphisms in the evolution of patients. Therefore, we were not literally doing a random search of a meaningful result, and our results should not be affected by the fact of carrying out a high number of statistical tests. Moreover, since $\mathrm{p}$ value is depending on the sample size, only big effects would be detected in small populations and it may be possible that we did not find any significant adjusted $\mathrm{p}$ value in some comparisons due to our size-limited population. We should take into account the fact that the effect size of our study is low since complex human diseases are under the control of many genes, each one of them contributing with modest individual effects [50].

There are other aspects to be taken into account for the correct interpretation of the results. Firstly, this is a cross-sectional study with data collected retrospectively. Secondly, the study contains a limited number of patients, which could limit achieving statistically significant $p$ values in some groups and it may lead to potentially large percentage fluctuations in the proportion. Thirdly, all selected patients met a set of criteria for starting HCV treatment and this may have introduced a selection bias. Fourthly, this study was performed on patients with European ancestry, and it would be interesting to perform these analyses on different ethnic groups. Fifthly, our study only included HIV/HCV-coinfected patients and it would be interesting to know the role of studied $I L 7 R$ polymorphisms in $\mathrm{HCV}$ monoinfected patients, but we did not have access to a cohort of HCV monoinfected patients. 


\section{Conclusions}

The presence of $I L 7 R$ polymorphisms seems to be related to severe liver disease in $\mathrm{HIV} / \mathrm{HCV}$ coinfected patients, because patients with unfavorable IL7R genotypes (rs6897932 CC, rs987106 TT, and rs3194051AA) had a worse prognosis of $\mathrm{CHC}$.

\begin{abstract}
Abbreviations
HIV: human immunodeficiency virus; HCV: hepatitis C virus; CART: combination antiretroviral therapy; IL-7: interleukin-7; IL7R: interleukin-7 receptor-alpha gene; IL7R $\alpha$ or CD127: high-affinity $\alpha$-chain of IL-7 receptor; CD132: common cytokine receptor gamma chain; pegIFNa/ribavirin: pegylated interferon alpha plus ribavirin; PCR: polymerase chain reaction; BMI: body mass index; IDU: intravenous drug use; HOMA: homeostatic model assessment; APRI: aspartate aminotransferase to platelet ratio index; AST: aspartate aminotransferase; ALT: alanine aminotransferase; $F \geq 3$ : advanced fibrosis; $A 3$ : severe activity grade; LD: linkage disequilibrium; HWE: Hardy-Weinberg equilibrium; aOR: adjusted odds ratio; SVR: sustained virological response.
\end{abstract}

\section{Authors' contributions}

MGF and SR performed all statistical analysis, interpretation of the data and wrote the manuscript. JB and SR participated in the study concept and design. $J B, A C, T A E, F T$, and CD participated in the selection of patients, collection of samples and acquisition of data. DPT, PGB, MAJS, SVM and MGA participated in sample preparation, DNA isolation and genotyping pre-procedure, and contributed with critical revision of the manuscript. SR supervised the study. SR drafted the final manuscript. All authors read and approved the final manuscript.

\section{Author details \\ ${ }^{1}$ Unidad de Infección Viral e Inmunidad, Centro Nacional de Microbiología, Instituto de Salud Carlos III (Campus Majadahonda), Carretera Majada- honda-Pozuelo, Km 2.2, Majadahonda, 28220 Madrid, Spain. ${ }^{2}$ Unidad de Enfermedades Infecciosas/VIH, Hospital General Universitario "Gregorio Marañón", Madrid, Spain. ${ }^{3}$ Instituto de Investigación Sanitaria Gregorio Marañón (liSGM), Madrid, Spain.}

\section{Acknowledgements}

The authors wish to thank the Spanish National Genotyping Center (CeGen) for providing the genotyping services (http://www.cegen.org). We also acknowledge the patients in this study for their participation.

\section{Funding/support}

This work has been supported by grants from Fondo de Investigación de Sanidad (FIS) [PI11/01556, PI14/01094, PI11/00245, PI14CIII/00011], and Fundación para la Investigación y la Prevención del Sida en España (FIPSE) [361020/10]. Besides, this work has been (partially) funded by the RD12/0017/0024 and RD12/0017/0004 projects as part of the Plan Nacional R + D + I and cofinanced by ISCIII-Subdirección General de Evaluación y el Fondo Europeo de Desarrollo Regional (FEDER). JB is an investigator from the Programa de Intensificación de la Actividad Investigadora en el Sistema Nacional de Salud (I3SNS) [INT10/009 and INT12/154]. DPT, MGF, MAJS, MGA, and PGB are supported by Instituto de Salud Carlos III [grant numbers CM12/00043, RD12/0017/0024, CD13/00013, CD12/00442, and F112/00036, respectively].

"Este trabajo ha sido financiado por el proyecto RD12/0017, integrado en el Plan Nacional de I + D + I y cofinanciado por el ISCIII-Subdirección General de Evaluación y el Fondo Europeo de Desarrollo Regional (FEDER)".

\section{Compliance with ethical guidelines}

\section{Competing interests}

The authors declare that they have no competing interests.

Received: 20 December 2014 Accepted: 19 June 2015

Published online: 30 June 2015

\section{References}

1. Pellegrini M, Calzascia T, Toe JG, Preston SP, Lin AE, Elford AR et al (2011) IL-7 engages multiple mechanisms to overcome chronic viral infection and limit organ pathology. Cell 144:601-613

2. Liang B, Hara T, Wagatsuma K, Zhang J, Maki K, Miyachi H et al (2012) Role of hepatocyte-derived IL-7 in maintenance of intrahepatic NKT cells and T cells and development of B cells in fetal liver. J Immunol 189:4444-4450

3. Noguchi M, Nakamura Y, Russell SM, Ziegler SF, Tsang M, Cao X et al (1993) Interleukin-2 receptor gamma chain: a functional component of the interleukin-7 receptor. Science 262:1877-1880

4. Capitini CM, Chisti AA, Mackall CL (2009) Modulating T-cell homeostasis with IL-7: preclinical and clinical studies. J Intern Med 266:141-153

5. Paiardini $M$ (2011) Editorial: hijacking the IL-7/IL-7R system in HIV infection. J Leukoc Biol 89:491-493

6. Hou L, Jie Z, Desai M, Liang Y, Soong L, Wang T et al (2013) Early IL-17 production by intrahepatic T cells is important for adaptive immune responses in viral hepatitis. J Immunol 190:621-629

7. Shin EC, Park SH, Nascimbeni M, Major M, Caggiari L, de Re V et al (2013) The frequency of CD127(+) hepatitis C virus (HCV)-specific T cells but not the expression of exhaustion markers predicts the outcome of acute $\mathrm{HCV}$ infection. J Virol 87:4772-4777

8. Larrea E, Riezu-Boj Jl, Aldabe R, Guembe L, Echeverria I, Balasiddaiah A et al (2014) Dysregulation of interferon regulatory factors impairs the expression of immunostimulatory molecules in hepatitis $C$ virus genotype 1-infected hepatocytes. Gut 63:665-673

9. Larrubia JR, Lokhande MU, Garcia-Garzon S, Miquel J, Gonzalez-Praetorius A, Parra-Cid T et al (2013) Persistent hepatitis C virus (HCV) infection impairs HCV-specific cytotoxic T cell reactivity through $\mathrm{Mcl}-1 / \mathrm{Bim}$ imbalance due to CD127 down-regulation. J Viral Hepat 20:85-94

10. Haralambieva IH, Ovsyannikova IG, Kennedy RB, Vierkant RA, Pankratz VS, Jacobson RM et al (2011) Associations between single nucleotide polymorphisms and haplotypes in cytokine and cytokine receptor genes and immunity to measles vaccination. Vaccine 29:7883-7895

11. Sudenga SL, Wiener HW, Shendre A, Wilson CM, Tang J, Shrestha S (2013) Variants in interleukin family of cytokines genes influence clearance of high risk HPV in HIV-1 coinfected African-American adolescents. Hum Immunol 74:1696-1700

12. Mazzucchelli RI, Riva A, Durum SK (2012) The human IL-7 receptor gene: deletions, polymorphisms and mutations. Semin Immunol 24:225-230

13. Limou S, Melica G, Coulonges C, Lelievre JD, Do H, McGinn S et al (2012) Identification of IL7RA risk alleles for rapid progression during HIV-1 infection: a comprehensive study in the GRIV cohort. Curr HIV Res 10:143-150

14. Rajasuriar R, Booth DR, Gouillou M, Spelman T, James I, Solomon A et al (2012) The role of SNPs in the alpha-chain of the IL-7R gene in CD4+ T-cell recovery in HIV-infected African patients receiving suppressive CART. Genes Immun 13:83-93

15. Guzman-Fulgencio M, Berenguer J, Pineda-Tenor D, Jimenez-Sousa MA, Garcia-Alvarez M, Aldamiz-Echevarria T et al (2015) Association between IL7RA polymorphisms and the successful therapy against HCV in HIV/ HCV-coinfected patients. Eur J Clin Microbiol Infect Dis 34:385-393

16. Mocroft A, Ledergerber B, Katlama C, Kirk O, Reiss P, d'Arminio Monforte A et al (2003) Decline in the AIDS and death rates in the EuroSIDA study: an observational study. Lancet 362:22-29

17. Lewden C, May T, Rosenthal E, Burty C, Bonnet F, Costagliola D et al (2008) Changes in causes of death among adults infected by HIV between 2000 and 2005: the "Mortalite 2000 and 2005" surveys (ANRS EN19 and Mortavic). J Acquir Immune Defic Syndr 48:590-598

18. Lo Re V 3rd, Kallan MJ, Tate JP, Localio AR, Lim JK, Goetz MB et al (2014) Hepatic decompensation in antiretroviral-treated patients co-infected with HIV and hepatitis C virus compared with hepatitis $C$ virus-monoinfected patients: a cohort study. Ann Intern Med 160:369-379

19. Lin W, Weinberg EM, Chung RT (2013) Pathogenesis of accelerated fibrosis in HIV/HCV co-infection. J Infect Dis 207(Suppl 1):S13-S18

20. Lopez-Dieguez M, Montes ML, Pascual-Pareja JF, Quereda C, Von Wichmann MA, Berenguer J et al (2011) The natural history of liver cirrhosis in HIV-hepatitis C virus-coinfected patients. AIDS 25:899-904 
21. Macias J, Berenguer J, Japon MA, Giron JA, Rivero A, Lopez-Cortes LF et al (2009) Fast fibrosis progression between repeated liver biopsies in patients coinfected with human immunodeficiency virus/hepatitis $C$ virus. Hepatology 50:1056-1063

22. Lo Re V 3rd, Kostman JR, Amorosa VK (2008) Management complexities of HIV/hepatitis C virus coinfection in the twenty-first century. Clin Liver Dis 12:587-609, ix

23. Thein HH, Yi Q, Dore GJ, Krahn MD (2008) Natural history of hepatitis C virus infection in HIV-infected individuals and the impact of HIV in the era of highly active antiretroviral therapy: a meta-analysis. AIDS 22:1979-1991

24. Brau N, Salvatore M, Rios-Bedoya CF, Fernandez-Carbia A, Paronetto F, Rodriguez-Orengo JF et al (2006) Slower fibrosis progression in HIV/HCVcoinfected patients with successful HIV suppression using antiretroviral therapy. J Hepatol 44:47-55

25. (2010) Panel de expertos de Gesida Plan Nacional sobre el Sida y Asociación Española para el Estudio del Hígado: [Recommendations of Gesida/PNS/AEEH for the management and treatment of the adult patient co-infected with HIV and hepatitis A, B and C virus]. Enferm Infecc Microbiol Clin 28:31 e31-31

26. (2009) Panel de expertos de Gesida y Plan Nacional sobre el Sida: [Recommendations from the GESIDA/Spanish AIDS Plan regarding antiretroviral treatment in adults with human immunodeficiency virus infection (update February 2009)]. Enferm Infecc Microbiol Clin 27:222-235

27. Thorpe LE, Ouellet LJ, Hershow R, Bailey SL, Williams IT, Williamson J et al (2002) Risk of hepatitis C virus infection among young adult injection drug users who share injection equipment. Am J Epidemiol 155:645-653

28. Matthews DR, Hosker JP, Rudenski AS, Naylor BA, Treacher DF, Turner RC (1985) Homeostasis model assessment: insulin resistance and beta-cell function from fasting plasma glucose and insulin concentrations in man. Diabetologia 28:412-419

29. Wai CT, Greenson JK, Fontana RJ, Kalbfleisch JD, Marrero JA, Conjeevaram HS et al (2003) A simple noninvasive index can predict both significant fibrosis and cirrhosis in patients with chronic hepatitis C. Hepatology 38:518-526

30. Sterling RK, Chiu S, Snider K, Nixon D (2008) The prevalence and risk factors for abnormal liver enzymes in HIV-positive patients without hepatitis B or C coinfections. Dig Dis Sci 53:1375-1382

31. Resino S, Sanchez-Conde M, Berenguer J (2012) Coinfection by human immunodeficiency virus and hepatitis $C$ virus: noninvasive assessment and staging of fibrosis. Curr Opin Infect Dis 25:564-569

32. Resino S, Seoane JA, Bellon JM, Dorado J, Martin-Sanchez F, Alvarez E et al (2011) An artificial neural network improves the non-invasive diagnosis of significant fibrosis in HIV/HCV coinfected patients. J Infect 62:77-86

33. Bedossa P, Poynard T (1996) An algorithm for the grading of activity in chronic hepatitis C. The METAVIR Cooperative Study Group. Hepatology 24:289-293

34. Park JH, Gail MH, Weinberg CR, Carroll RJ, Chung CC, Wang Z et al (2011) Distribution of allele frequencies and effect sizes and their interrelationships for common genetic susceptibility variants. Proc Natl Acad Sci USA 108:18026-18031
35. Fan JB, Oliphant A, Shen R, Kermani BG, Garcia F, Gunderson KL et al (2003) Highly parallel SNP genotyping. Cold Spring Harb Symp Quant Biol 68:69-78

36. Gregory SG, Schmidt S, Seth P, Oksenberg JR, Hart J, Prokop A et al (2007) Interleukin 7 receptor alpha chain (IL7R) shows allelic and functional association with multiple sclerosis. Nat Genet 39:1083-1091

37. Kreft KL, Verbraak E, Wierenga-Wolf AF, van Meurs M, Oostra BA, Laman JD et al (2012) Decreased systemic IL-7 and soluble IL-7Ralpha in multiple sclerosis patients. Genes Immun 13:587-592

38. Crawley AM, Faucher S, Angel JB (2010) Soluble IL-7R alpha (sCD127) inhibits IL-7 activity and is increased in HIV infection. J Immunol 184:4679-4687

39. Hartling HJ, Thorner LW, Erikstrup C, Harritshoj LH, Kronborg G, Pedersen C et al (2014) Polymorphism in interleukin-7 receptor alpha gene is associated with faster CD4(+) T-cell recovery after initiation of combination antiretroviral therapy. AIDS 28:1739-1748

40. Santiago JL, Alizadeh BZ, Martinez A, Espino L, de la Calle H, FernandezArquero $M$ et al (2008) Study of the association between the CAPSL-IL7R locus and type 1 diabetes. Diabetologia 51:1653-1658

41. Guo L, Du Y, Chang S, Zhang K, Wang J (2014) rSNPBase: a database for curated regulatory SNPs. Nucleic Acids Res 42:D1033-D1039

42. Broux $B$, Hellings $N$, Venken $K$, Rummens JL, Hensen $K$, Van Wijmeersch B et al (2010) Haplotype 4 of the multiple sclerosis-associated interleukin-7 receptor alpha gene influences the frequency of recent thymic emigrants. Genes Immun 11:326-333

43. Page EE, Nelson M, Kelleher P (2011) HIV and hepatitis C coinfection: pathogenesis and microbial translocation. Curr Opin HIV AIDS 6:472-477

44. Jager J, Schulze C, Rosner S, Martin R (2013) IL7RA haplotype-associated alterations in cellular immune function and gene expression patterns in multiple sclerosis. Genes Immun 14:453-461

45. Garcia-Samaniego J, Rodriguez M, Berenguer J, Rodriguez-Rosado R Carbo J, Asensi V et al (2001) Hepatocellular carcinoma in HIV-infected patients with chronic hepatitis C. Am J Gastroenterol 96:179-183

46. Clifford GM, Rickenbach M, Polesel J, Dal Maso L, Steffen I, Ledergerber B et al (2008) Influence of HIV-related immunodeficiency on the risk of hepatocellular carcinoma. AIDS 22:2135-2141

47. Ciuffreda D, Kim AY (2011) Update on hepatitis C virus-specific immunity. Curr Opin HIV AIDS 6:559-565

48. Perneger TV (1998) What's wrong with Bonferroni adjustments. BMJ 316:1236-1238

49. Sterne JA, Davey Smith G (2001) Sifting the evidence-what's wrong with significance tests? BMJ 322:226-231

50. Burton PR, Tobin MD, Hopper JL (2005) Key concepts in genetic epidemiology. Lancet 366:941-951

\section{Submit your next manuscript to BioMed Central and take full advantage of:}

- Convenient online submission

- Thorough peer review

- No space constraints or color figure charges

- Immediate publication on acceptance

- Inclusion in PubMed, CAS, Scopus and Google Scholar

- Research which is freely available for redistribution

Submit your manuscript at 